\title{
Removal of Dyes of Textile Rejects by Activated Carbon
}

\author{
K. Elmerzouki ${ }^{1, *}$, I. Bimaghra ${ }^{1}$ and A. Khalidi ${ }^{2}$ \\ ${ }^{1}$ UH2C, Ecole Normale Supérieur, Laboratoire Ingénierie des Matériaux et Biosciences, Casablanca, \\ Morocco \\ ${ }^{2}$ UH2C, FST, Mohammedia, Morocco
}

\begin{abstract}
The composition of wastewater from the textile industry varies enormously from one moment to another depending on the nature of the dyes used, the type of tissue, methods used and the concentration of added chemicals. In most cases the dye effluents are characterized by strong color, high temperatures, high and random values of $\mathrm{pH}$, amounts of suspended solids and COD-concentrations close to the limit values set by the draft Moroccan standards.

The study of turbidity indicates a variation between 120 and 190 NTU for the three samples. As for their conductivity varies between 5,2 and $20 \mathrm{mS} . \mathrm{cm}^{-1}$. Moreover their $\mathrm{pH}$ varies in the field of basic $\mathrm{pH}$. Measuring the temperature of these three samples showed values varying between 25 and $30^{\circ} \mathrm{C}$. The levels of suspended solids range between 146,8 and $514,7 \mathrm{mg} \mathrm{L}^{-1}$.

The results show that the measured absorbance at $436 \mathrm{~nm}$ decreased to 2,020 A and it stabilizes at this value. To the absorbance of the color measured at $525 \mathrm{~nm}$ decreases to $3,072 \mathrm{~A}$ and it stabilizes. The absorbance measured at the wavelength $620 \mathrm{~nm}$ decreases and reaches a minimum value of $1,918 \mathrm{~A}$ after ten hours.
\end{abstract}

Keywords: Activated carbon, turbidity, absorbance, adsorption, waste water.

\section{INTRODUCTION}

In the textile industry the water and chemicals products are consumed during the manufacturing process. The chemicals products used are diverse. An significant portion Is located in downstream of the process circuits in discharges and sewage especially in dyes. Among thesis compounds, there are significant quantity of suspended solids, Dispersing agents, salts, metals traces and high concentrations of COD [1]. There are wide quantities of various dyes [2] this account for Two Thirds of total market [3]. The annual textile production is about 30 million tons and require 7 $10^{5}$ tons of dyes. What deriving a significant source of pollution [4] and having a detrimental impact on the environment.

To fight against this huge problem of pollution of effluents from the textile industry, several technical treatment-have-been tested. Biological processes (aerobic and anaerobic) are cheaper. However, thesis technical are sensitive to poorly biodegradable dyes [5]. In addition, a wide variety of physicochemical met photolysis, coagulation flocculation [8], chemical oxidation, ion exchange, photo catalysis [9] and membrane filtration.

In this study we studied the wastewater of industrial textile unit. After characterizing the wastewater the

${ }^{*}$ Correspondence Address to this author at the UH2C, Ecole Normale Supérieur, Laboratoire Ingénierie des Matériaux et Biosciences, Casablanca, Morocco; Tel: 0662267222; E-mail: elmer_khad@yahoo.fr trials treatment by adsorption in CAB, were conducted at the laboratory scale, by studying the removal of color and turbidity.

\section{MATERIEL AND METHODS}

\subsection{Characterization of Reject}

The wastewater from the textile industry especially the dyeing effluents containing organic dyes, chemicals products, salts, detergents, heavy metals and other [10]. So Wastewater from dyeing contains the main pollutants in the textile industry [2].

To assess the pollution discharged by this type of industry in the environment, a physicochemical characterization was performed for the overall dyeing effluent chosen for this study. Table 1 shows the analysis results of three different samples taken just before the point of discharge of sewage into the urban drainage system.

The results show that the physicochemical characteristics of the textile effluent vary from sample to another. Indeed, the composition of the wastewater from the textile industry varies enormously from one moment to another depending on the nature of the dyes used, the type of tissue, methods used and the concentration of added chemicals [11, 12]. In most cases the dye effluents are characterized by strong color, high temperatures, high and random values of $\mathrm{pH}$, amounts of suspended solids and CODconcentrations close to the limit values set by the draft Moroccan standards [13, 14]. 
Table 1: Physicochemical Characterization of Wastewater of Dyeing

\begin{tabular}{|c|c|c|c|c|}
\hline Paramètre & Sample I & Sample II & Sample III & $\begin{array}{c}\text { limite value (Draft Moroccan } \\
\text { Standard) }\end{array}$ \\
\hline Conductivité (ms/cm) & 20,1 & 5,2 & 12,5 & - \\
\hline Turbidité (NTU) & 190 & 120 & 145 & - \\
\hline $\mathrm{pH}$ & 12 & 7,9 & 11,15 & $6,5-8,5$ \\
\hline $\begin{array}{c}\mathrm{T}\left({ }^{\circ} \mathrm{C}\right) \\
\operatorname{Mes}\left(\mathrm{mgL}^{-1}\right)\end{array}$ & $\begin{array}{c}30,2 \\
514,7\end{array}$ & $\begin{array}{l}28,7 \\
238\end{array}$ & $\begin{array}{c}25 \\
146,8\end{array}$ & $35-600$ \\
\hline $\begin{array}{l}\mathrm{NO}_{3}^{-}\left(\mathrm{mgL}^{-1}\right) \\
\mathrm{SO}_{4}{ }^{2-}\left(\mathrm{mgL}^{-1}\right)\end{array}$ & $\begin{array}{l}300,2 \\
360,7\end{array}$ & $\begin{array}{l}225 \\
266\end{array}$ & $\begin{array}{c}14,2 \\
342,3\end{array}$ & --400 \\
\hline $\begin{array}{c}\mathrm{PO}_{4}^{3-}\left(\mathrm{mgL}^{-1}\right) \\
\mathrm{Cl}^{-}\left(\mathrm{mgL}^{-1}\right)\end{array}$ & $\begin{array}{l}2,33 \\
4986\end{array}$ & $\begin{array}{c}3,1 \\
3325\end{array}$ & $\begin{array}{c}3,4 \\
2873\end{array}$ & -- \\
\hline $\begin{array}{c}\mathrm{Pt}\left(\mathrm{mgL}^{-1}\right) \\
\mathrm{DCO}\left(\mathrm{mgL}^{-1}\right)\end{array}$ & $\begin{array}{l}35,2 \\
797\end{array}$ & $\begin{array}{c}13 \\
606,8\end{array}$ & $\begin{array}{c}10,13 \\
681\end{array}$ & $10-1000$ \\
\hline Abs(436nm) & - & 0,433 & - & - \\
\hline $\operatorname{Abs}(525 \mathrm{~nm})$ & - & 0,567 & - & - \\
\hline $\operatorname{Abs}(625 \mathrm{~nm})$ & - & 0,723 & - & - \\
\hline
\end{tabular}

The study of turbidity indicates a variation between 120 and 190 NTU for the three samples. As for their conductivity varies between 5,2 and $20 \mathrm{mS} . \mathrm{cm}-1$. Moreover their $\mathrm{pH}$ varies in the field of basic $\mathrm{pH}$, with high values and that sometimes exceed the range limit set by the Moroccan draft standards. This strongly influences the quality of wastewater and can have several impacts on the receiving environment. Indeed, the $\mathrm{pH}$ has a direct effect on living organisms. Measuring the temperature of these three samples showed values varying between 25 and $30^{\circ} \mathrm{C}$. The levels of suspended solids range between 146.8 and $514.7 \mathrm{mg} \mathrm{L}^{-1}$ (Table 1). These changes in $\mathrm{pH}$, temperature, TSS and conductivity are comparable to those reported by [13-15].

These samples are rich in organic matter. Indeed, COD levels recorded in Table 1 range from 606-797 $\mathrm{mgL}^{-1}$. These values coincide with the results of $[8,13-$ $15]$. Moreover, their phosphorus levels vary between 10 and $35 \mathrm{mg} \mathrm{L}^{-1}$. These results are superior to those reported by [14]. This high load of oxidable materials is mainly due to chemicals products, and organic dyes and the nature of the cellulose fibers (Table 1) used during the dyeing process.

In addition to the significant organic load, these samples show high concentrations of sulfate, chlorides and nitrates. The sulphate content vary between 266 and $360 \mathrm{mg} \mathrm{L}^{-1}$. While addition, high levels of chloride ions were detected $\left(2.87\right.$ to $\left.4.98 \mathrm{~g} \mathrm{~L}^{-1}\right)$. Nitrate ions recorded alarming values ranging from 14.2 to $300 \mathrm{mg}$ $\mathrm{L}^{-1}$, their use by aquatic plants accelerates their uncontrolled spread and contributes to oxygen depletion by inhibiting photosynthesis.

Textile effluents discharges are complex, loaded with organic and inorganic materials. They have varying characteristics with time and can be toxic of microorganisms. The negative impact of the rejection of this effluent on the receiving environment proves indisputable and requires pretreatment prior to discharge. On the other hand, and any project of a pollution control industry, a homogenization basin is necessary.

\subsection{Process Used}

The method applied to the treatment of the effluent from the textile industry is summarized in the following scheme:

Settling and adjusting the $\mathrm{pH}=1.2$ of the effluent $50 \mathrm{ml}$ $+0.6 \mathrm{~g}$ activated carbon

\section{$\downarrow$}

(Or different masses in case of mass effect study) Agitation for 26 hours at $\mathrm{T}=20 \pm 2{ }^{\circ} \mathrm{C}$

$$
\downarrow
$$

Filtering the suspension

$\downarrow$

Analysis of physicochemical parameters: $\mathrm{pH}$, conductivity, turbidity and absorbance $(436 \mathrm{~nm}, 525 \mathrm{~nm}$ and $620 \mathrm{~nm}$ ) 


\section{RESULTS AND DISCUSSION}

\subsection{Study of the Adsorption}

\subsubsection{Monitoring Changes of Conductivity, Turbidity and $\mathrm{pH}$ during Processing}

In order to know the impact of the supportadsorbing on $\mathrm{pH}$, conductivity and turbidity of industrial waste, we tried to measure these parameters during treatment with activated carbon.
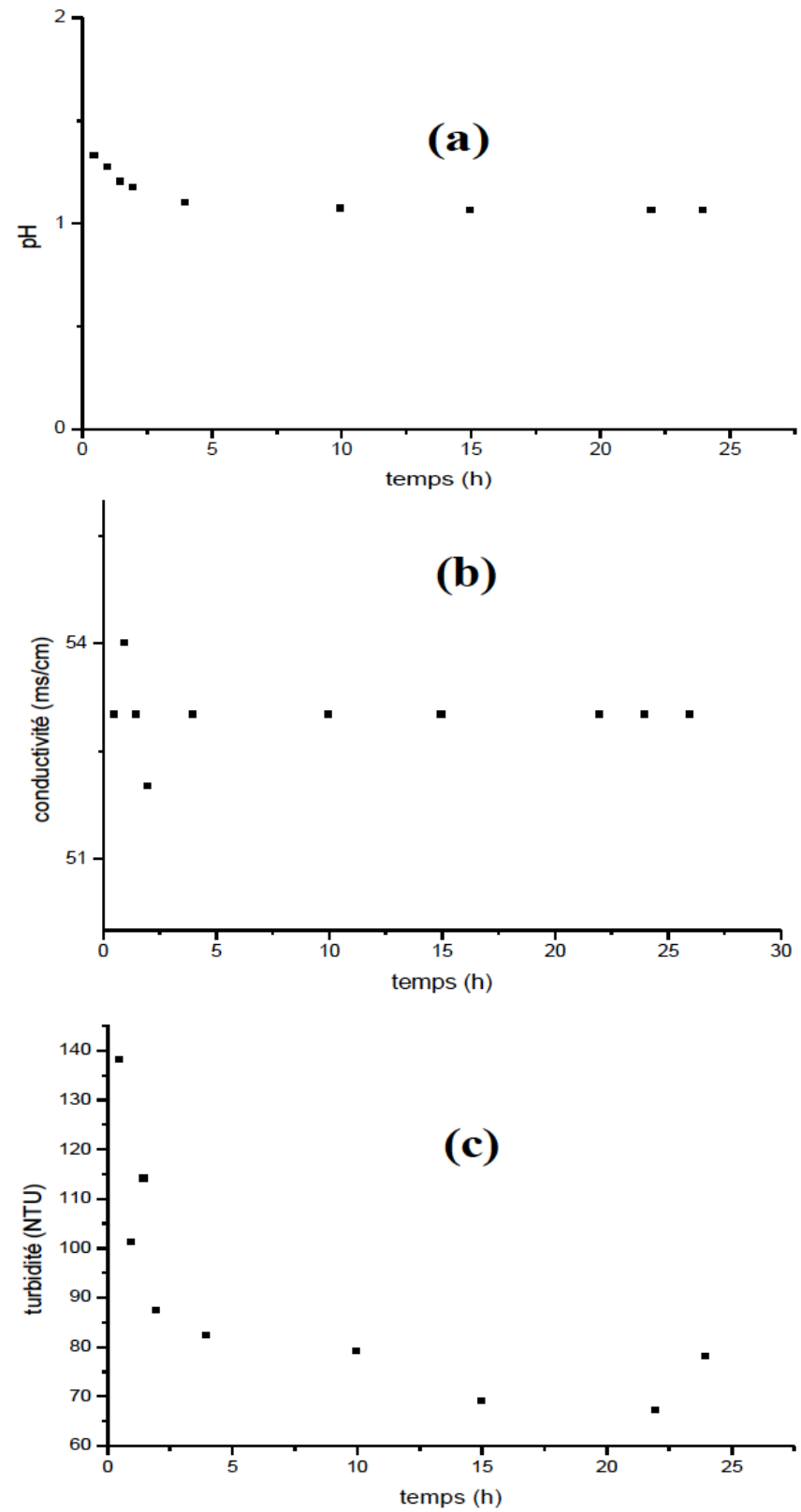

Figure 1: Monitoring changes of conductivity, turbidity and $\mathrm{pH}$ during processing.

$m_{\text {ads }}=12 \mathrm{~g} \cdot \mathrm{L}^{-1}, \mathrm{pH}_{\mathrm{i}}=1,2, \mathrm{v}=50 \mathrm{~mL}$ et $\mathrm{T}=20^{\circ} \mathrm{C}$.

The monitoring results of the change in $\mathrm{pH}$, conductivity and turbidity of the effluent during treatment by activated carbon (Figure 1), show that these parameters not aware of any significant variation in reported to the mass of material used. On the curve (a) of Figure 1, we see just a small decrease in initial $\mathrm{pH}$ value $\left(\mathrm{pH}_{0}=1.33\right)$ during the first four hours, then stabilized at 1.06 to the minimum value from tenth hour. Curve (b) shows the conductivity ranges from 53 $\mathrm{ms} \mathrm{cm}{ }^{-1}$ to $52 \mathrm{~cm}^{-1} \mathrm{~ms}$ and passes by the value of 54 $\mathrm{ms}^{-1} \mathrm{~cm}$ during the first four hours. As a result it is stabilized at the value of $53 \mathrm{~ms}^{-1} \mathrm{~cm}$. This shows that no release of ions was observed for the mass of the activated carbon used.

While the curve (c) show that turbidity decreased during treatment, she spends 138 to the minimum 67 NTU during the first 22 hours, followed by a small increase in the value of 78 NTU. This means that the turbidity is heavily eliminated by activated carbon over time.

\subsubsection{Monitoring the Change in Color in Function of Time}

Studies on the effect of the contact time between the $C A B$ adsorbent and the adsorbate are of considerable importance. Rapid fixing of adsorbate and steady establishment in a short duration means the effectiveness of the adsorbent so that it is used in the treatment of wastewater.

The monitoring results of the color variation for the wavelengths $436 \mathrm{~nm}, 525 \mathrm{~nm}$ and $620 \mathrm{~nm}$, in the contact time during the adsorption of the color of the effluent, are illustrated in Figure 2.

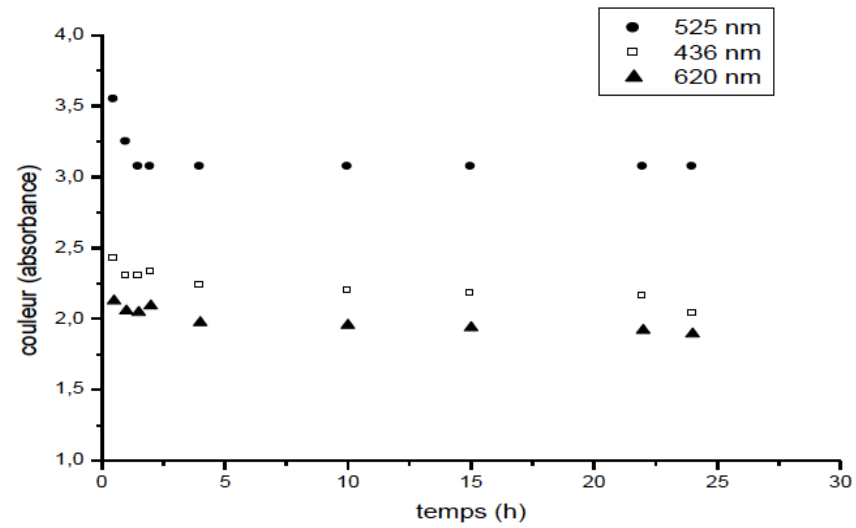

Figure 2: Monitoring the change in color in function of time. $\mathrm{m}_{\text {ads }}=12 \mathrm{~g} \cdot \mathrm{L}^{-1}, \mathrm{pH}_{\mathrm{i}}=1,2, \mathrm{v}=50 \mathrm{~mL}$ et $\mathrm{T}=20^{\circ} \mathrm{C}$.

These results show that the absorbance measured at $436 \mathrm{~nm}$ decreases from $2.426 \mathrm{~A}$ to $2.240 \mathrm{~A}$ for the first four hours. Thereafter, we do not see significant 
changes, it is almost stable at the minimum value of 2,200 A for 20 hours following.

To the absorbance of the color measured at $525 \mathrm{~nm}$ decreases of $3.547 \mathrm{~A}$ to $3.072 \mathrm{~A}$ for the initial two hours. Thereafter, it stabilizes the 3,072 Aminimum value.

The absorbance measured at the wavelength 620 $\mathrm{nm}$ decreases and reaches a minimum value after ten hours. During the first four hours the absorbance of the staining decreased to $2,125 \mathrm{~A} 1,972 \mathrm{~A}$, to stabilize at a minimum value of $1,918 \mathrm{~A}$ after ten hours of stirring.

Staining measured at three wavelengths $(436 \mathrm{~nm}$, $525 \mathrm{~nm}, 620 \mathrm{~nm}$ ) decreases during the time of treatment. This confirms the elimination of dyes by activated carbon adsorption. This can be explained by the fact that a large number of vacant sites on the adsorbate surface are available for adsorption during the initial stage. And thereafter, the occupation of the rest of vacant surface sites became difficult. This is due to the repulsive forces between the molecules of dyes adsorbed on the adsorbent, and the molecules of the dyes of the liquid phase [4]. The three curves are similar.

\subsection{Study of the Mass Effect}

\subsubsection{Monitoring Changes of Conductivity, Turbidity and $\mathrm{pH}$ during Processing}

After each treatment trial, we measured the $\mathrm{pH}$, turbidity and conductivity rejection based on the mass of $\mathrm{CAB}$, to see the effect of the mass of adsorbent used on these physicochemical parameters. The results are shown in Figure 3.

From the curve (a) of Figure 3 we see a slight decrease in the $\mathrm{pH}$ of the medium from 1.60 to 1.1 , for a variation of the $C A B$ mass used of $0.3 \mathrm{~g}$ to $0.8 \mathrm{~g}$.

On the curve (b) of the same figure, which represents the variation of the conductivity with the CAB mass used, the conductivity shows a small decrease. It goes from $42.4 \mathrm{~ms} / \mathrm{cm}$ to $41 \mathrm{mS} / \mathrm{cm}$ when the $C A B$ mass increases from $0.3 \mathrm{~g}$ to $0.6 \mathrm{~g}$. Then it stabilizes at the minimum value of $41 \mathrm{mS} / \mathrm{cm}$ even if we add more CAB mass. This may be due to the fact that no release of ions was observed for all the masses of the activated carbon used.

Curve (c) of Figure 3 shows the variation of the turbidity as a function of the amount of discharge of $\mathrm{CAB}$ used. This curve shows a small increase in the turbidity of 27.09 NTU to 29.2 NTU, followed by a decrease of $29.2 \mathrm{NTU}$ at the minimum value of 12.5 NTU when the CAB mass Password of $0.3 \mathrm{~g}$ to $0.6 \mathrm{~g}$. In following with the increase of the mass used, the turbidity remains constant at the minimum value of 12.5 NTU. This means that the turbidity is eliminated by the CAB over time.
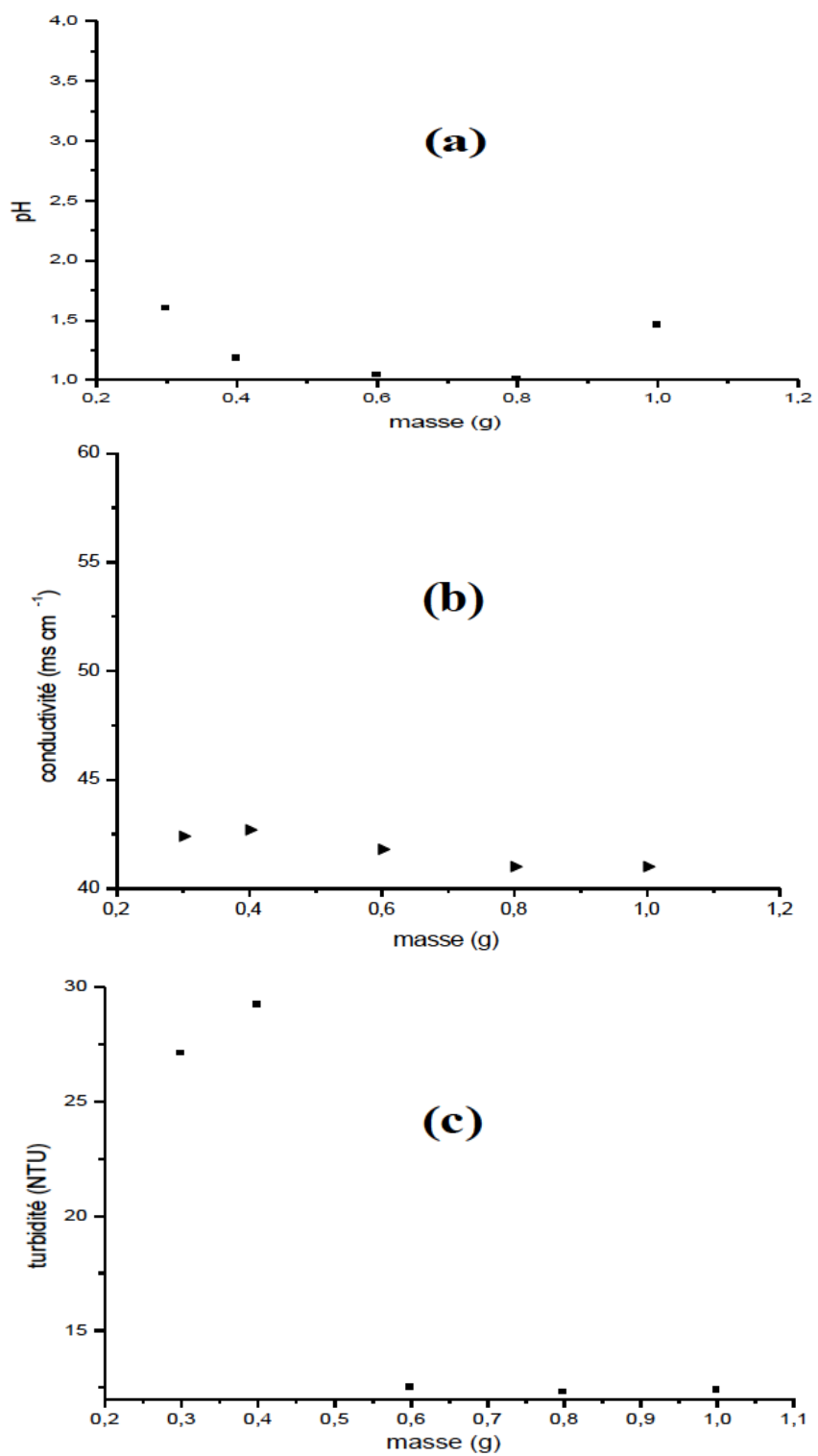

Figure 3: Monitoring changes of conductivity, turbidity and $\mathrm{pH}$ during processing.

$m_{\text {ads }}=12 \mathrm{~g} \cdot \mathrm{L}^{-1}, \mathrm{pH}_{\mathrm{i}}=1,2, \mathrm{v}=50 \mathrm{~mL}$ et $\mathrm{T}=20^{\circ} \mathrm{C}$.

\subsubsection{Monitoring the Change in Color in Function of Time}

As well as for the study of the adsorption, during the treatment with different masses, we measured the absorbance of the color to the three wavelengths 436 $\mathrm{nm}, 525 \mathrm{~nm}$ and $620 \mathrm{~nm}$ as a function of the mass (Figure 4). 
The curve of the absorbance at the wavelength 436 $\mathrm{nm}$, shows that the latter knows a decrease of $0.03 \mathrm{~A}$ to a minimum of $0.007 \mathrm{~A}$ with the increase of $\mathrm{CAB}$ mass to $0.8 \mathrm{~g}$ of $50 \mathrm{ml}$ of solute. Then, with the increase in the mass, the absorbance appears almost without change.

In the same figure, the curve of the absorbance at the wavelength of $525 \mathrm{~nm}$, shows the decrease in absorbance of $0.096 \mathrm{~A}$ to the minimum value of 0.051 A for a dose of $0.8 \mathrm{~g}$ of CAB.

To the absorbance at the wavelength $620 \mathrm{~nm}$ shown in Figure 4, it also decreases of $0.078 \mathrm{~A}$ to $0.013 \mathrm{~A}$ when the $C A B$ mass used increases from $0.3 \mathrm{~g}$ to $0.8 \mathrm{~g}$. Then it is stabilized at the minimum value of $0,013 \mathrm{~A}$ with increasing $\mathrm{CAB}$ mass.

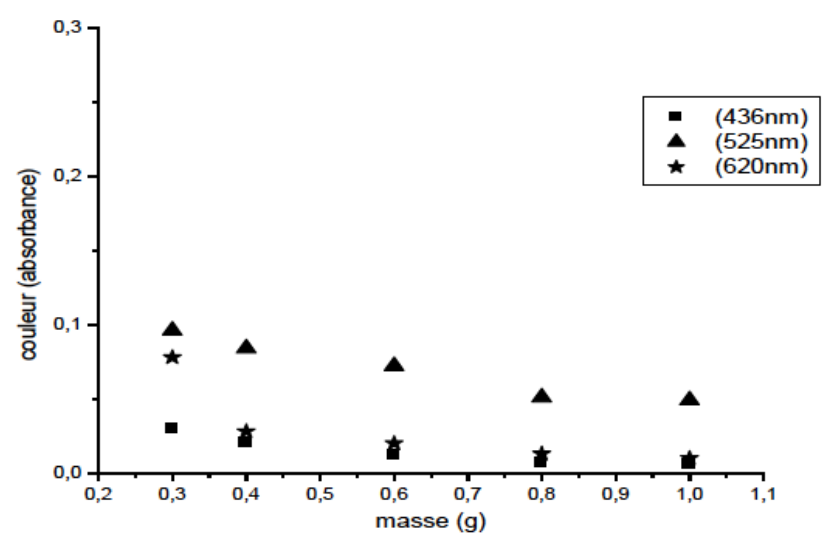

Figure 4: Suivi monitoring the change in color in function of mass.

$m_{\text {ads }}=12 \mathrm{~g} \cdot \mathrm{L}^{-1}, \mathrm{pH}_{\mathrm{i}}=1,2, \mathrm{v}=50 \mathrm{~mL}$ et $\mathrm{T}=20^{\circ} \mathrm{C}$.

So we find that the color removal to the three wavelengths increases to a maximum value. And then remains constant with increasing $C A B$ mass. Indeed for high masses of $C A B$, there is more than the number of active sites available for the molecules of adsorbate which will travel to the solution to the surface of the cabinet in order to look for these active sites. From these experimental results we conclude that for proper disposal must be used an optimal amount of neighboring $C A B$ of $16 \mathrm{~g} / \mathrm{L}$.

\section{CONCLUSION}

This study qualitatively and quantitatively evaluates the effluents from the textile industry whose waste water is discharged into the receiving environment without any treatment.

The rejection of the textile industry is a rejection loaded in color, it has a basic $\mathrm{pH}$. Treatment with activated carbon helps to reduce the levels of dyes so that they obey the standards. Monitor the conductivity, $\mathrm{pH}$ and turbidity during the treatment of this rejection has shown that changes in the conductivity and $\mathrm{pH}$ may be negligible compared to the contribution of the support to the elimination of dyes.

The adsorption treatment results show that activated carbon:

- The kinetics activated carbon adsorption is characterized by a slow saturation time (4 hours).

- Removal of textile dyes with activated carbon shows that the adsorption process is important depending on the mass of the adsorbate. Indeed, the active carbon reduction allowed almost all dyes to a mass of $16 \mathrm{~g} / \mathrm{l}$.

\section{REFERENCES}

[1] Tak-Hyun K, Chulhwan $P$, Eung-Bai S, Sangyong K. Decolorization of disperse and reactive dye solutions using ferric chloride. Desalination 2004; 161: 49-58. http://dx.doi.org/10.1016/S0011-9164(04)90039-2

[2] Sadki H, Ziat K, Saidi M. Adsorption d'un colorant cationique d'un milieu aqueux sur une argile locale active. Journale of Mater Environ Sci 2014; 5(S1): 2060-2065.

[3] Anouar H, Elhourch A, Elkacemi K, Zouahra A. Removal of orange 16 azo dye by adsorption on powdered activated carban. International Journal of Innovation and Applied Studies 2014; 9: 1373-1377.

[4] Srivastava VC, Mall ID, Mishra IM. Treatment of pulp and paper mill wastewaters with poly aluminium chloride and bagasse fly ash. Colloids and Surfaces A 2005; 260: 17-28. http://dx.doi.org/10.1016/j.colsurfa.2005.02.027

[5] Georgiou D, Melidis P, Aivasidis A, Gimouhopoulos K. Degradation of azo-reactive dyes by ultraviolet radiation in the presence of hydrogen peroxide. Dyes and Pigments 2002; 52: 69-78. http://dx.doi.org/10.1016/S0143-7208(01)00078-X

[6] Lai WL, Lin SH, Yeh HH, Tseng IC, Kao SJ, Chen JJ, Wang TG. Comparison of the finished water quality among an integrated membrane process, conventional and other advanced treatment processes. Desalination 2000; 131: 237244.

http://dx.doi.org/10.1016/S0011-9164(00)90022-5

[7] Chu W, Tsui SM. Modeling of photodecoloration of azo dye in a cocktail photolysis system. Water Research 2002; 36: 3350-3358.

http://dx.doi.org/10.1016/S0043-1354(02)00021-0

[8] Georgiou D, Melidis P, Aivasidis A. Scale-up and design optimization of anaerobic immobilized cell reactors for wastewater treatment. Chemical Engineering and Processing 2003; 42: 897-908.

http://dx.doi.org/10.1016/S0255-2701(02)00124-1

[9] Hachem C, Bocquillon F, Zahraa O, Bouchy $M$. Decolourization of textile industry wastewater by the photocatalytic degradation process. Dyes and Pigments 2001; 49: 117-125.

http://dx.doi.org/10.1016/S0143-7208(01)00014-6 
[10] Golob V, Vinder A, Smonie M. Efficiency of the coagulation/floculation method for the treatment of dyebath effluent. Dyes and Pigments 2005; 67: 93-97. http://dx.doi.org/10.1016/j.dyepig.2004.11.003

[11] Al-Degs Y, Khraisheh MAM, Allen SJ, Ahmad MN. Effect of carbon surface chemistry on the removal of reactive dyes from textile effuent. Water Research 2000; 34: 927-935. http://dx.doi.org/10.1016/S0043-1354(99)00200-6

[12] Talarposhti AM, Donnelly T, Anderson GK. Colour removal from a simulated dye wastewater using a two-phase Anaerobic packed bed reactor. Water Research 2001; 35: 425-432. http://dx.doi.org/10.1016/S0043-1354(00)00280-3

[13] Sangyong K, Chulhwan P, Tak-Hyun K, Jinwon L, SeungWook K. COD reduction and decolorization of textile effluent using a combined process. Journal of Bioscience and Bioengineering 2003; 95: 102-105.

http://dx.doi.org/10.1016/S1389-1723(03)80156-1

[14] Kapdan IK, Alparslan S. Application of anaerobic-aerobic sequential treatment system to real textile wastewater for color and COD removal. Enzyme and Microbial Technology 2005; 36: 273-279.

http://dx.doi.org/10.1016/j.enzmictec.2004.08.040

[15] Azbar N, Kestioglu K. Comparison of various advanced oxidation processes and chemical treatement methods for COD and color removal from a plyester and acetate fiber dyeing effluent. Chemosphere 2004; 55: 35-43. http://dx.doi.org/10.1016/j.chemosphere.2003.10.046 